\title{
Dimensions of Adaptive Water Governance and Drought in Argentina and Canada
}

\author{
Margot Ann Hurlbert ${ }^{1,2}$ \& Elma Montana ${ }^{3}$ \\ ${ }^{1}$ University of Regina, Canada \\ ${ }^{2} \mathrm{Ph}$.D. candidate, the University of Amsterdam, Netherlands \\ ${ }^{3}$ Inter American Institute for Global Change Research (IAI), Uruguay \\ Correspondence: Margot Ann Hurlbert, University of Regina, Canada. E-mail: Margot.Hurlbert@uregina.ca
}

Received: October 21, 2014 Accepted: November 5, 2014 Online Published: January 28, 2015

doi:10.5539/jsd.v8n1p120 URL: http://dx.doi.org/10.5539/jsd.v8n1p120

\begin{abstract}
Climate change in many local and regional scales is expected to include climate hazards and extreme conditions including hailstorms, droughts, floods, hurricanes, hail, tornadoes and storms. Droughts are serious climate hazards threatening water supply for human consumption and also agricultural production and are anticipated to increase in intensity and duration in both Mendoza, Argentina and southern Alberta, Canada.

Both Mendoza and Alberta have irrigated agriculture and their rivers are fed primarily by snowmelt and rainfall runoff from mountainous headwaters. Many similarities exist between water law and governance in the Mendoza river basin, Argentina and the Oldman river basin in southern Alberta, Canada. However, many differences also exist. Can these governance systems ensure the continuation of agricultural production in the area into the future given increased development and climate change?

Utilizing the institutional design principles of adaptive capacity and water governance, this paper will compare and contrast the water governance institutional structures in the two study areas. Data was obtained from two multi-disciplinary studies of institutional adaptation to climate change studying vulnerability of local agricultural producers and communities to climate change, and the interplay of water governance structures, and adaptive capacities. The water governance systems of both countries show concerns relating to gaps in information and equitable outcomes; in addition there are concerns of a lack of capacity to enable reflexivity. Both systems have been responsive (although there is room for improvement). Through strengthening these identified weaknesses these systems can continue to be resilient into the future.
\end{abstract}

Keywords: adaptive governance, climate change, drought planning, extreme weather, water governance

\section{Introduction}

There is increasing consensus that the impacts of climate change will not be uniform; there may be a readjustment among the components of regional climate systems creating conditions of unexpected climate patterns including loss of species, invasion of non-native species, changes in regional ecosystems, sea levels, precipitation patterns, as well as increased flooding and water scarcity (Parry et al., 2007). More intensive and longer droughts are expected in many regions. An increase in the number of days with high temperatures, are expected to impact people, animals, and plants (IPCC, 2014; Parry et al., 2007; Brown, 2007; Henson, 2006). There is medium confidence that the length or number of warm spells or heat waves has increased as well as some areas are experiencing more intense and longer droughts such as in central North America (IPCC, 2012, p. 6, 11). Economic losses from weather and climate related disasters have increased (ibid., p. 7). The arguments about a potential "tipping point" in the near future add another level of complexity in that the process of climate change may be non-gradual and potentially dangerous, filled with sudden and abrupt changes to natural and social systems (Henson, 2006: 16; Brown, 2007: 42-45).

The advantages of irrigation as an adaptation option for drought relief were documented by Wheaton et al. (2008) for both eastern and western Canada. In Alberta, farmers with irrigated lands would have distinct advantages over those with rain-fed lands during drought. Irrigators would be able to gain from the potential of increased prices and better yields. The situation is even more contrasted in the drylands of western Argentina, where agriculture is only possible through systematic irrigation (Montaña et al., 2005). This paper interrogates how 
water governance structures may facilitate these dryland irrigated areas to weather a future changing climate.

In Alberta, Canada, although irrigation is not anticipated to increase, increases in human and livestock use of water is expected to stress the water resource with per capita consumption of groundwater doubling by 2057 and an eighteen per cent projected decline in groundwater to occur because of human use of the land (Cardston County, 2011, p. 13). With a historically unstable economy and a restructuring agriculture industry, it is difficult to predict the future of the irrigation in Mendoza, Argentina; but there are few doubts about the population's growing pressure on irrigated lands, sprawling cities and difficulties for making the water uses more efficient in the context of unmanaged water demands (DGI, 2013; Montaña, 2011; Secretaría de Ambiente, 2010; UNCuyo, 2004).

The institution of governance is important in not only mitigating climate change through both climate change policy and energy policy, but also reducing vulnerability of many groups in society. Environmental governance is challenged in responding to climate change developments and the complex system of the anthropocene. Past accommodation of climate conditions made by government and policy, will be inadequate to respond to the increasing variability of climate patterns and potentially sudden and abrupt changes. An emerging governance frame, adaptive governance, seeks to respond to this complexity (Folke et al., 2005) by stressing the characteristics of social learning, reflexivity, responsiveness, and accountability operating in a system where science is contextual, knowledge is incomplete and multiple ways of knowing and understanding are present (Brunner \& Steelman, 2005). This paper will consider water governance in relation to irrigation farmers of Alberta, Canada, and Mendoza, Argentina, in the context of climate change, extreme drought, and adaptive governance. First the study areas' governance of water and drought will be reviewed, which will be followed by a review of adaptive water governance dimensions. After outlining our methodology, the study areas of Alberta and Mendoza will be assessed utilizing key concepts of adaptive governance. This paper will conclude with recommendations to improve water governance in the future.

\section{Government Policy on Water and Drought}

In Alberta, Canada, water is predominantly under provincial jurisdiction, although several aspects are not including First Nations' land and international rivers, which are under the jurisdiction of the federal government (Hurlbert, 2009). Programming on drinking water, flood hazard identification, groundwater, lake water quality, surface water quality, etc. are handled by Alberta Environment and Sustainable Resource Development ("Alberta Environment") (Andrews, 2012). This department links with the Alberta Water Council and other entities (including irrigation districts and associations) involved in water. Adaptation to climate change is partly the responsibility of Alberta Environment overseeing the Climate Change Adaptation Framework and Alberta Agriculture which hosts a suite of producer adaptation programs (in conjunction with the Canadian government) (Alberta Environment and Sustainable Resource Development, n.d.).

Response to drought is coordinated by the Alberta Drought Management Committee and since 2001 Alberta has had an Agriculture Drought Risk Management Plan setting out government action plans for response to drought that focuses on preparedness, monitoring, and response (Government of Alberta, 2010). This plan establishes linkages to other relevant policies and plans (such as climate change), outlines activities for drought preparedness, monitoring, reporting and response (ibid.). Also, this Ministry provides weekly Agriculture Moisture Situation Updates during the growing season and monthly during the winter season as a part of general drought-related programming. The federal government funds programs which the Alberta government manages (and also financially contributes to). These programs assist producers by stabilizing income (Agri-stability), providing insurance for crop loss, and preparing land to be drought resilient by building infrastructure (Hurlbert et al., 2010).

In Argentina, water resources are under provincial jurisdiction and the heaviest responsibilities for facing drought reside at the provincial level, especially in central-western Argentinean dry lands, far from the federal capital. Coping with emergency is not as institutionally developed in the Argentinean case. From the higher provincial ranking position, the water agency (Departamento General de Irrigación, DGI) formulates and executes the provincial water policies and decentralizes operations in users' organizations called Inspecciones de Cauce. At the provincial level there is an office charged of coping with climatic emergencies (the Dirección de Prevención de Contingencias Climáticas), but it is mainly concerned to avoid agricultural damages from hail and leaves all water issues to the powerful DGI, which does not have specific emergency plans. Also working at the provincial level is the Environment Secretariat and its Climatic Change Office. This office, however, is mainly a bureaucratic formality, as it has only one person specifically assigned and no budget of its own, and the Secretariat itself has minor influence over water and drought management compared to the strength of the 
production/development-oriented management conducted by the DGI. In this hydraulic society of wine producers, this agency embodies the interests of the agricultural users of water over others such as environmental and social that are relegated (Montaña, 2008), with the exception of the drinking water sector that is prioritized in the legislation.

Government systems are different in Canada and in Argentina in several aspects. Canada has adopted a federal system, where the federal and provincial governments assume responsibilities in different areas and in different degrees. Water rights, the prerogative of provincial governments in Canada, are allocated predominately based on "first in time first in right" rules. In Alberta, there is the ability to transfer interests in water under certain circumstances and in certain situations; however, an active water market is not yet in existence. Some areas in Alberta (which includes the study region) are fully allocated and have experienced shortages. The last one was in 2001. Although the ultimate arbitrator of these disputes is a court of law, the government does have some ability to attempt resolution of water disputes arising as a result of shortage. Overall, the Canadian water governance system is characterized as a decentralized, multi-level governance system (Hurlbert, 2006b; Johns and Rasmussen, 2008; Bakker, 2007).

The constitutions of Argentina and Mendoza recognize water to be a public good under the general administration of provincial government (Lee, 1990; Baars, 1995). A bill has been proposed to recognize water as a natural strategic resource that is essential for life in addition to stating it to be the government's responsibility to ensure that the fundamental human right to water and sanitation is guaranteed throughout Argentina (S-2362/09, Proyecto de Modificacion a la Ley de Gestion Ambiental de Aguas, Art 3). No ability to transfer water interests exists in Mendoza as it does in Alberta. Agricultural water rights are assigned to a piece of land and are non-transferable. Further, water fees must be paid in respect of the assigned right whether used or not. This fee is based on a flat rate and not an actual usage (DGI, 2007) and has a small incidence in the costs of farmers. No water market is possible and the rigid water rights structure, as well as bureaucratic blockades, and this pricing structure constitutes a very rigid water governance system, in which it is very difficult to promote more efficient ways of using water. Water shortages situations are addressed by simply reducing the amount of water provided at an equal rate for all users having the same type of water rights, the older ones having better chances of being fulfilled than the more recent ones. However, it is a paradox that in the context of this unequal society, the water governance inflexibility turns out to be a shield for small powerless agricultural landowners, preventing them from losing their water rights in times of water shortage or economic distress.

\section{Adaptive Water Governance}

The concept of adaptive governance emerged in order to respond to ecosystem dynamics in order to actively manage the interplay of gradual and abrupt change. Governance systems (the political, social, economic and administrative systems that manage resources, in this case water) embracing the principles of adaptive governance encourage resilience (Berkes \& Folke, 1998). Resilience refers to the persistence or robustness of either or both natural or human communities in the face of a disturbance (Folke, 2006, 253). When a vulnerable social-ecological system has lost resilience it has suffered a loss of adaptability (Berkes \& Folke, 1998, 262). In these terms, the concept of adaptive governance refers not only to the capacity of governance to face and reduce the impacts of external stressors upon its internal institutions, but also to its capacity to extend this resilience to a variety of systems (such as water systems or ecological systems) that, although are not directly part of governance, are under its influence (Folke, 2006; Berkes \& Folke, 1998).

Adaptive governance recognizes the interconnectedness of present, past and future human and biophysical systems and attempts to respond to significant challenges including complexity, uncertainty and change, and problems of fragmentation (Holling, 1978; Gunderson, 1999; Dietz et al, 2003). Adaptive governance relies on different underlying sources of authority operating at multiple levels (Burris et al., 2005; Lebel et al. 2006). In relation to water, adaptive governance is sited as a new generation of governance institutions for resolving collective action problems in relation to water that occur between different types of resource users and different agencies tasked with resolving these conflicts (Scholz and Stiftel, 2005; Mollenkamp \& Kasten 2009, Huntjens et al 2012, Young 2011, Cook et al 2011, Hill 2012, Huitema et al. 2009). Dimensions of adaptive governance (Note 1) are characteristics that governance regimes should have in order to be adaptive, to practice adaptive governance, or to respond to climate change (Huitema et al., 2009; Folke et al. 2005; Gunderson, 2002; Olsson et al. 2006). The number of dimensions tends to vary depending on the author, ranging from a few characteristics, such as the six dimensions listed in the work of Gupta et al. (2010) to a long suite of attributes, as those identified by Cook et al. (2011) and there tends to be overlap, various permutations, groupings and emphasis. For the purposes of this paper the following categories found in both Gupta et al. (2010) and Huntjens et al. (2012) are used: 
1) Responsiveness - the ability of governance networks, organizations and actors to respond appropriately and in a timely manner to climate variability, hazards and extreme events in a manner that accounts for ecosystem dynamics.

2) Reflexivity - the social learning aptitude of water and extreme climate events governance institutions.

3 ) Access to information in such a way as there is an ability and capacity to respond and change autonomously.

4) Capacity - the informational, human, and social capital in existence necessary to respond appropriately to climate variability, hazards, and extreme events.

5) Equity - the fairness of the water and extreme climate events governance regime in process and impact.

(Gupta et al. 2010; Huitema et al., 2009)

These dimensions will be used to analyze the governance of water in both the Alberta, Canada, and Mendoza, Argentina, cases.

\section{Methodology}

The data used in this paper was generated in the context of multi-disciplinary studies of institutional adaptation to climate change in Canada (Diaz and Warren, 2012; Diaz et al. 2009) and Argentina. In the latter, the vulnerability assessment was made through research work in two projects: a comparative two-year interdisciplinary effort funded by the InterAmerican Institute for Global Change Research (IAI)-- sought to identify and characterize the vulnerabilities of rural actors to climate variability and climate-induced water problems in the basins of the Mendoza, Choquecota, and Elqui rivers (see Salas, Jimenez, Montaña et al, 2012; Diaz et al, 2012, Montaña, 2008) and another one carried out by Dr. Montaña with CLACSO-CROP support, focusing on the links between poverty and climate vulnerability and took place on the river basins of Mendoza, Pucara, and Elqui (Montana, 2012 and 2013).

Both regions are dry land river basins and employ irrigation relying on stream flow, but have very different governance regimes. A map of the study regions appears on Figures 1 and 2.

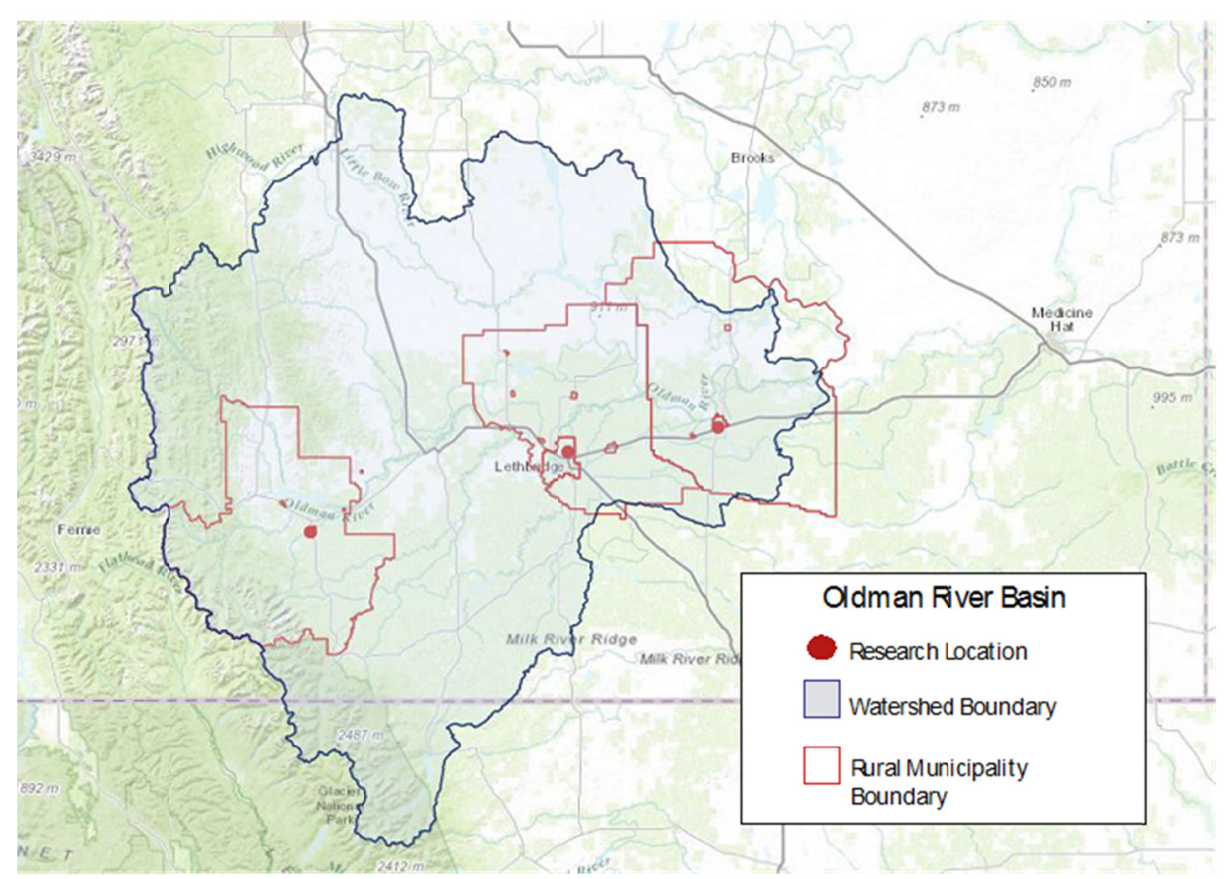

Figure 1. Oldman river study area (Brodie, 2014) 


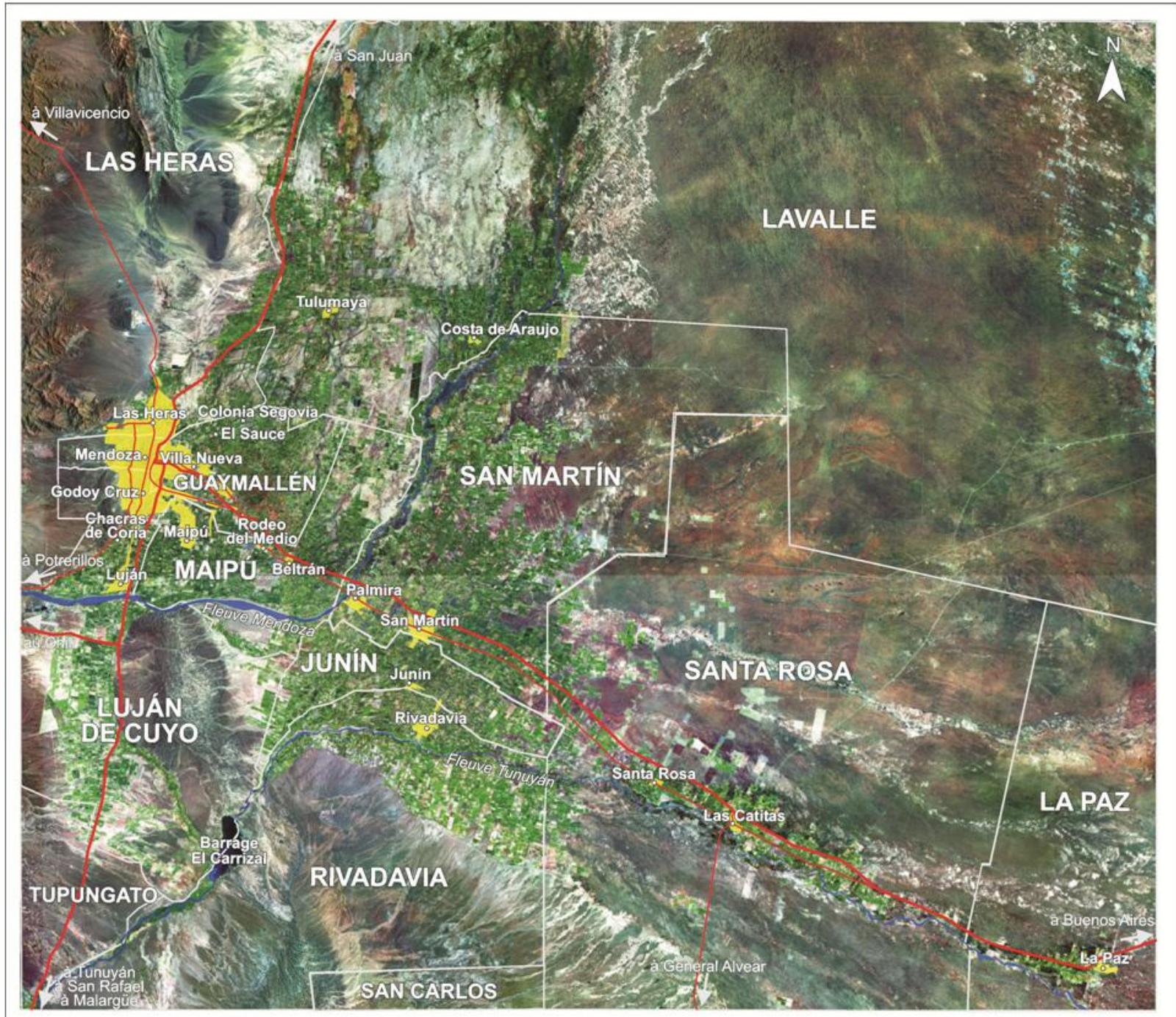

Figure 2. Mendoza River Basin

The projects focused on vulnerability as determined by exposure and sensitivity and interaction of these processes with adaptive capacity determined through the existence of bundles of assets available to local producers and communities (IPCC, 2001; Smit and Wandel, 2006). Institutional water governance was an important determinant of adaptive capacity as it is one bundle of assets accessible for adapting to extreme events such as drought. Figure 3 represents the interrelationship of the concepts of vulnerability and the bundles of assets (economic resources, technology etc.). The projects had a community vulnerability assessment and a water governance assessment component. 


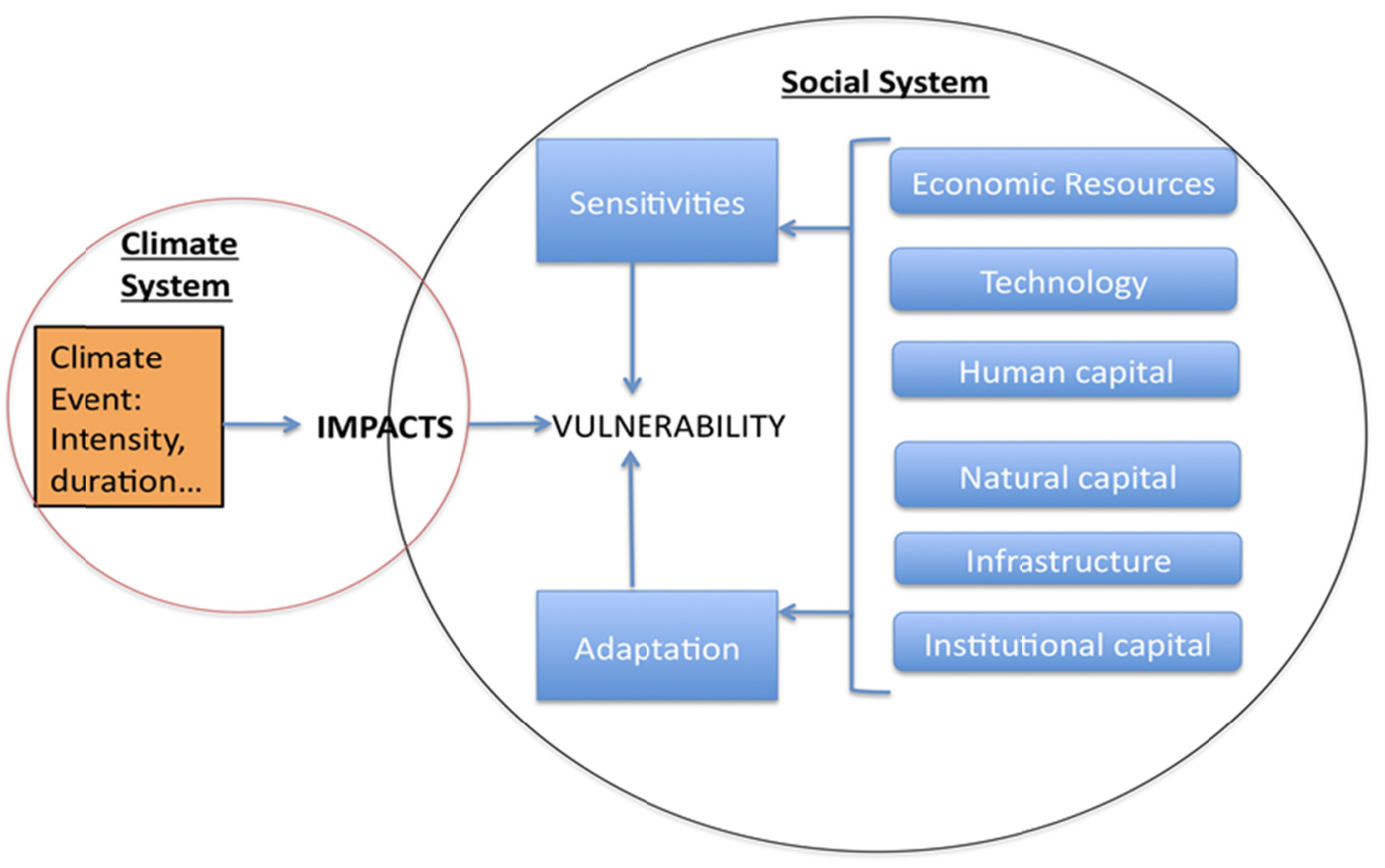

Figure 3. Relationship of vulnerability (adaptation/sensitivities and institutional capital)

(Diaz and Hurlbert, 2011)

Community vulnerability assessments employed semi-structured qualitative interviews with local community members and agricultural producers exploring their vulnerability to climate and specifically drought and their adaptive practices reducing their sensitivities. The Alberta study interviewed 31 community members (Prado, 2008), 26 provincial, and 10 federal government personnel involved in the water governance sector (Wandel, 2009). Community members were selected utilizing a snowball method and project partners of the study assisted in identifying water governance personnel with a deep understanding of climate change and water governance. In Mendoza, 46 rural producers were interviewed, according to a representative sampling that considered actor's typology, type of agricultural production and location in the basin. Another 25 semi-structured interviews were applied to institutional representatives, covering the water, environmental and productive and sectors in the local, provincial and national levels with competency in the basin (Montaña, 2012:321-329). All interviews were recorded, transcribed and then loaded in the qualitative analysis software NVivo as cases described with respect to certain attributes that allowed subsequent filtering as needed to isolate specific informants or issues. The texts of the interviews were coded into nodes in a tree structure, in accordance with the variables on which the interview guides were organized. This analytical scheme allowed specific queries across variables and type of informants.

As part of the community vulnerability assessment, we asked the communities to identify governance issues impacting the vulnerability of the communities searching for governance practices assisting agricultural producers, and those increasing their sensitivity. They expressed concerns about the complexity of water governance, limited responses to their problems, and limited information about weather, climate, and climate change (Diaz et al 2009; Salas, Jimenez, Montaña et al, 2012; Diaz et al, 2012; Montaña, 2008). Around these issues we correlated these concerns with some relevant institutional design principles identified in the literature then integrating them into the governance assessment. These institutional design principles include responsiveness (knowing who to contact and receiving action and answers), capacity (information and leadership), learning (having experienced previous extreme events), and equity (communities without water).

Information for the governance assessment was obtained from multiple sources, including public documents, focus group sessions, and in-depth semi structured qualitative interviews with representatives of water users, associations, watershed and environmental groups, community representatives, and all orders of government involved in water governance. Information about a wide array of organizational and procedural issues was 
gathered, including sources of climate information and data, past responses to situations of water stress, and long term planning in relation to future climate and water stress.

\section{Assessing Adaptive Capacity of Irrigators in Argentina and Canada}

Analysis of the key elements of adaptive governance in Mendoza and Alberta is summarized on Table 1. Each of these elements will be covered below. Because of significant institutional fragmentation the water governance structures lack responsiveness and reflexivity, access to information and capacity are all impacted because of this as well. Although Canada shows some promise for reflexivity and social learning, rigidity and old cultural practices in Argentina prevent the demonstration of this design principle. Capacity is being eroded because of aging farmers and equity issues exist in both study areas.

Table 1. Key elements of adaptive water governance in Mendoza and Alberta

\begin{tabular}{|c|c|c|c|}
\hline $\begin{array}{l}\text { Adaptive } \\
\text { Governance }\end{array}$ & & Argentina & Canada \\
\hline Responsiveness & & $\begin{array}{l}\text { Coordination, integration, and conflict } \\
\text { management is hampered by institutional } \\
\text { arrangements }\end{array}$ & $\begin{array}{l}\text { Coordination, integration, and conflict } \\
\text { management is hampered by institutional } \\
\text { arrangements }\end{array}$ \\
\hline $\begin{array}{l}\text { Reflexivity } \\
\text { Social Learning }\end{array}$ & and & $\begin{array}{l}\text { No integrated water planning exists yet } \\
\text { Institutional rigidity; ground water, } \\
\text { surface water is disconnected }\end{array}$ & $\begin{array}{l}\text { Watershed groups are emerging as an } \\
\text { important element of governance. } \\
\text { Principles of integrated water planning are } \\
\text { being re-implemented }\end{array}$ \\
\hline $\begin{array}{l}\text { Access } \\
\text { Information }\end{array}$ & to & $\begin{array}{l}\text { Data Gaps in Water Demand and } \\
\text { Groundwater }\end{array}$ & Data Gaps in Water Availability \\
\hline Capacity & & $\begin{array}{l}\text { Marginalized social capital due to rigid } \\
\text { aging farmers }\end{array}$ & $\begin{array}{l}\text { Marginalized social capital due to rigid } \\
\text { aging farmers } \\
\text { Reduction of capacity through civil servant } \\
\text { retirements }\end{array}$ \\
\hline & & $\begin{array}{l}\text { Consultations of public are of a small } \\
\text { scale }\end{array}$ & $\begin{array}{l}\text { Irrigation in Alberta is at maximum } \\
\text { capacity }\end{array}$ \\
\hline Equity & & $\begin{array}{l}\text { Urban activities threaten quality and } \\
\text { quantity of water available for agricultural } \\
\text { production }\end{array}$ & \\
\hline & & $\begin{array}{l}\text { Existence of Vulnerable populations (goat } \\
\text { herders and small oasis farmers) }\end{array}$ & $\begin{array}{l}\text { Existence of Vulnerable populations (dry } \\
\text { land farmers and First Nations) }\end{array}$ \\
\hline
\end{tabular}

\subsection{Responsiveness}

The responsiveness of the water governance systems in Mendoza and Alberta could be improved in several respects. Coordination (due to fragmentation of water resource management), integration, and conflict management are all challenges limiting the responsiveness and flexibility of water governance.

In Canada, a multitude of water organizations exists at the provincial and municipal level, making interagency coordination an issue (Hurlbert et al., 2010). Complexity creates confusion even amongst government officials themselves, let alone stakeholders and the general public (Diaz et al., 2009). A need to establish clear roles and coordinate water activities was discovered in participant interviews and focus groups (ibid.). A further constraint of "first in time/first in right" licensing exists. Although water transfers are allowed in Alberta, the development of further irrigation systems and the provision to new rural residents (including some municipalities) is constrained by this system (Diaz et al., 2009).

In Argentina two major areas of fragmentations exist. First, because of the federal nature of its government 
system, no single national water authority or one national water law in Argentina exists and a diversity of institutions exists (Pochat et al., 2006). The two main institutions are the Departamento General de Irrigacion (DGI) of the Mendoza government, and the Inspecciones de Cauce, the users' organizations. This Inspecciones are public, non-state, autonomous and autocratic organs with a capacity to act in a public and private legal capacity overseeing the surface water rights system. The responsibilities and activities of the DGI and the Inspections are not clearly defined, but the organization is shown as an example on how the public and the private sectors can work together resulting in a close-to-the-soil administration (Salomón, 2009; Pinto, 2006). The DGI grants groundwater licenses in a centralized way, sometimes by an expedited procedure that prioritizes responsiveness for powerful actors (MDZPolítica, 2013; Sivera 2013a,b; El Sol, 2013). In this way surface water and groundwater is accessed by agricultural producers through two separate, independent institutions without any coordination.

The second institutional fragmentation concerning responsiveness in Mendoza is that while water allocation and use is regulated by the DGI and the organized users, land use in under the competence of the local government, the municipio. This local level is in the first line of responsiveness when an emergency affects rural dwellers and also takes care of some of the productive emergencies, but with no coordination with the DGI and the water governance system. Within the DGI and the Inspecciones de Cauce, drought management is still tied to the rigid water distribution system (Hurlbert et al., 2014). The situation is different in Alberta, Canada, where most water supply and infrastructure challenges are met by municipal governments and individual farm operators (Government of Alberta, 2010).

Alberta's responsiveness in the future does show cause for concern. The provincial and federal government agencies with experience and capacity to deliver rural water programming solutions to water-stressed communities and farmsteads are facing uncertain futures due to institutional rearrangements and decades of government attrition through neo-liberal policies (Diaz et al., 2009). Alberta also faces challenges with the threat to long-time Alberta Environment and Alberta Agriculture employees who may eventually retire or be replaced with people of lesser knowledge (Hurlbert \& Diaz, 2013). This shift will increasingly place more pressure on individual farmers and municipalities in relation to water governance. However, emergency responses in the cases of flood or extreme drought still are responded to by the municipal government with assistance from the provincial and national government.

Both countries will increasingly face water shortages and potential conflicts amongst current water rights holders as a result of climate change (Montaña, 2008; Masiokas et al., 2013; Rojas et al., 2007). Neither country has well established institutions to respond to these conflicts. Mendoza will resolve disputes through reducing water flows proportionally to the land surface, regardless the type of crop and if it is used or not, while the wealthiest producers will access the aquifers; in Canada civil society and water bureaucrats will be relied on. Not planning for increased conflict as a result of water shortages due to climate change increases vulnerability leading to further reductions in adaptive capacity. In Canada it is unclear, and in Argentina there is no doubt that the water governance system does not have the necessary responsiveness or flexibility to respond to the changing climate in the future.

\subsection{Reflexivity and Social Learning}

In order for a governance system to adapt to climate change and projected extreme events of drought, institutional governance systems must incorporate a degree of reflexivity and demonstrate social learning. Social learning is learning through organization, interaction, and collaboration of a network of interdependent stakeholders (Moster et al., 2007; Siebenhuner, 2008). In order to have social learning there must be a high degree of coordination and interaction between policy makers and stakeholders (Pahl-Wostl, 2010) and significant available information to allow the necessary monitoring and evaluation (Foxon et al., 2009). In order to assess the design principle of reflexivity and social learning, we considered: the reflexivity of policies and practices, and the vertical and horizontal integration of the water governance system as reflected in its ability to incorporate integrated watershed management.

Reflexive policies and practices are ones "that can anticipate and respond to an array of conditions that lie ahead, and can navigate towards successful outcomes when surprised by the unforeseen" (Venema \& Drexhage, 2009, p. 1). Rigid policies are unable to cope efficiently with the uncertainties and dynamics of new climate conditions and are not supported by a public institutional system able to reflect and learn constantly from experience and interaction. Implicit in institutional learning is preparedness to experiment, preventing rigid persistence and purposefulness of practice (Goodin, 1996). The institutional fragmentation described above in respect of both countries engenders a rigidity which limits the reflexivity available in any individual or water institution. 
Improving coordination and communication and building opportunities for inter-institutional involvement would improve institutional reflexivity.

In Mendoza an additional characteristic of institutional rigidity that hinders institutional learning is the difference in values between the old DGI, whose actions are guided by a productive concern under the XIX century paradigm of progress -today referred as "development and productivity" (DGI, 2013) and the more recent Secretariat of the Environment, whose actions seek to achieve sustainability and resource conservation. The antagonism is usually settled in favour of the influential DGI and the local economic powers (Montaña, 2008). In Canada, a system of environmental assessments, municipal land zoning, and citizen engagement generally mediates value conflicts, and supports a certain amount of reflexivity, although economic development is highly valued (Diaz et al., 2009).

Integrated watershed management is one tool used to facilitate vertical and horizontal coordination and allow for reflexivity and social learning. Integrated watershed management has emerged for consideration in both countries which is consistent with its adoption as a best practice (Global Water Partnership, 2009). Canada's experience with watershed groups and integrated watershed management planning has only occurred in the past several years. Alberta implemented integrated watershed planning recently, albeit the same approach was tried several decades earlier (Stewart, 2011). As a result, firm conclusions on the longevity and success of this initiative would be premature. As outlined above, the rigidity of the Argentine system does not allow the flexibility needed for integrated water management. Mendoza's provincial water law is more than a century old with water management involving the Departamento General de Irriagacion (DGI) and the Inspecciones de Cauce, the users' organizations. A Master Plan for Mendoza River Basin was developed in 2012 with very little consultation with the public and no real impact. DGI has a water plan "H2020" setting out plans for water (with no mention of climate change and adaptation) (DGI, n.d.). The Mendoza water governance system is not integrated (Diaz Araujo and Bertranou, 2004). It is interesting to point out that any attempt to unblock this constraint (i.e. to change the water law) is restrained by the fear of a more liberal regime that could reinforce the established economic powers in a similar way as the water market did in Chile. Responding to emergency conditions has emerged as a policy agenda. However, adaptive capacity and the reduction of vulnerability long term have not (Hurlbert et al., 2014).

Barriers to reflexivity and social learning in both countries include the existence of old paradigms of thinking as well as problem of horizontal and vertical integration, evidenced by an inability to implement integrated watershed management. This inability of either water governance system to demonstrate reflexivity and social learning is also a latent impact of the institutional fragmentation identified above. Additionally, problems with data accumulation and management identified below impede social learning as the necessary monitoring and assessing required is absent.

\subsection{Access to Information (Allowing the Capacity to Respond and Change Autonomously)}

In order to learn, institutional systems must be able to alter or modify policy approaches based on change. In order to assess whether or not change is occurring, these institutions must be able to collect and process information about key components of climate events. This information, of course, must be managed properly to reduce its complexity, and made available to a variety of stakeholders (Gupta et al., 2010). Agricultural producers require timely data for their livelihoods (in order to make decisions in the spring about crops) and local governments and agricultural producers also need long term data to make decisions respecting infrastructure (in order to assess costs and benefits of investing in water storage equipment for instance). Efficient data collection and data management systems are not only an indicator of a healthy institutional system, they are also the fundamental components of informational capital (which is an important determinant of adaptive capacity) (Hurlbert \& Diaz, 2013). Informational capital contributes to a better knowledge of existing resources and facilitates their management in situations of uncertainty and surprise. The existence of a solid accumulation and good use of information capital is a must in ensuring the social and economic sustainability of livelihoods and productive sectors (ibid.).

Both Argentina and Canada have gaps in climate and water quantity and quality data (Diaz et al., 2009; Salas, Jimenez, Montaña et al, 2012). Coordination of data bases and knowledge gaps of what data exists are issues. Funding of programs, as well as the collecting, storing and sharing of data are areas that have been cut in past years, contributing to this issue rather than remedying it. This lack of information is detrimental to the development of policies able to foster adaptive capacity to climate variability and climate change.

In Canada, many water data collection issues were reported in interviews. Identified gaps in the data pool (water quality, quantity and use, and climate data) were identified. Interviews disclosed a fair deal of uncertainty about 
what information is available, what can be accessed by whom, and who is responsible for collecting and sharing it (Diaz et al., 2009, p. 53). This challenge has impacted long-term planning (Corkal et al., 2011) in relation to the incorporation of future climate change (Note 2), planning for future water shortages (Wandel, 2009), and developing mechanisms to assist the resolution of issues across boarders (Corkal et al., 2010).

In Mendoza, there is relatively more data in climate and hydrology issues than data in respect of water demands (Salas, Jimenez, Montaña et al., 2012). The data about available water exists, but it needs further analysis and interpretation. On the other hand, data on water demands and uses is more scarce, diffuse and difficult to integrate in systematic analysis, which is essential for adaptive water management. In general terms, there are data gaps, but the greater needs are of structured information (data series, indicators, problem/objectives oriented information) and of the adoption of that information by decision and policy makers.

The data gaps existing in both Argentina and Canada are concerning for responding to climate variability and extremes into the future. Social learning may be impaired as a result of actors being uncertain of the current status and governance structures incapable of adapting and thus reducing vulnerability to the range of climate events expected. In Canada, challenges surrounding data availability have contributed to a deficit in long term planning (Hurlbert \& Diaz, 2013). No concerted and collaborative effort exists in respect of future climate change and often planning is limited by the election cycle. Alberta's drought plan focuses on short term coping strategies at the producer level. There is a need for a plan addressing the larger picture of water allocation during times of surface water shortage (Diaz et al., 2009). Addressing issues beyond provincial borders and an appropriate federal water policy and plan is lacking. Election cycles in both countries make long term planning in relation to water an issue. Scientific studies on the Mendoza river basin climate and hydrology (Boninsegna \& Villalba, 2006a \& b; Boninsegna \& Delgado, 2002) show that the last serious drought occurred in 1968 and that recent droughts, although currently perceived as serious, turn out to be mild in the context of a wider historical analysis, and that the big drought is yet to occur. The memories of the 1968's drought are lost and this knowledge is not established among government agencies and civil society; there are currently no systematic plans for water allocation during very severe droughts (Montaña \& Boninsegna, forthcoming).

In both countries, a very long term horizon of twenty to fifty years is reflected in climate change science. Governments rarely set binding legislation and policy with a planning time frame further than a few years into the future. It is very difficult to develop effective policies, plans, legislation and regulation given these time frame disparities. Large investments in water infrastructure required to adapt to future droughts anticipated by climate change are costly and hard to implement for political parties interested in re-election in a few years especially in difficult economic times.

Based on this analysis, the capacity of the water governance systems in Mendoza and Alberta to respond and change autonomously are impeded because of issues surrounding access to information. Information gaps exist in both regions (albeit in relation to different information) and there are issues of knowing what information exists, and accessing it. Provincial boarders create geographical issues in Canada and issues of time exist. Often climate science is too futuristic, droughts or extreme events have occurred too far in the past, and politicians and decision makers are operating on a four or five year elections cycle.

\subsection{Capacity (Including Leadership and Resources)}

Institutional capacity to respond to water shortages appears to be in a precarious position. Organizations in Canada traditionally involved in water governance are in transition; a reduction in programs and staff has occurred. Organizations in Argentina are mired in centuries old rules. Irrigation on both countries has strengthened the adaptive capacity of the irrigated farming industry, but it is unclear that any increase in irrigation can continue into the future. Irrigated agriculture has had implications for the next dimension of adaptive governance of "equity."

In Alberta a significant threat was the loss of institutional knowledge on water adaptation at the federal government department of Agri-Environment Services Branch (AESB, formerly PFRA) (Diaz et al., 2012). The institution of PFRA had the knowledge and skills to provide assistance to farmers in managing and responding to dry conditions including with infrastructure needs, crop needs and other informational needs. The loss of the institutional capacity may be a result of a failure to plan for climate change adaptation and increasingly neo-liberal policies (ibid.). The impact of this in Canada is the reduction of government bureaucracy and resultant services.

In Mendoza the aging farmers are resistant to change, partial to traditional irrigation practices, and not easily convinced to embrace newer irrigation practices. As an example, a so called "Tsunami irrigation" is used such that when water is available, it is liberally used, resulting in flooding of the soil and the stripping of the silt from 
the top soil (Salas, Jimenez, Montaña et al, 2012). One project attempted to transition Mendoza irrigators to take up drip irrigation but was rejected by users in the Water Users Assembly (Diaz Araujo \& Bertranou, 2004).

Positive developments also exist. In Argentina there are also institutions like the Instituto Nacional de Tecnología Agraria (INTA) that help farmers in improving and innovating their agricultural practices for reducing risks and increasing resiliency, although an old population of small producers with difficulties for generational renewal makes it difficult especially in the case of small producers (Mussetta, 2013). In Alberta a program targets improvement in irrigation efficiency specifically by offering $40 \%$ of costs (to a maximum of $\$ 5,000$ ) (Alberta Agriculture and Rural Development, n.d.).

There have been important positive developments that have reduced the exposure of rural communities to water scarcities in both countries. In Canada there are many civil society organizations participating in decisions relating to specific watersheds. In Alberta watershed groups and watershed councils exist, all organized under the provinces new Water for Life Strategy, created after Alberta recognized the province to be facing significant pressures on its water resources (Diez et al., 2009). There are still considerable institutional barriers to integrate these local based organizations in an effective way into water governance (ibid.). In Mendoza, a Master Plan for the Mendoza River Basin was developed in 2010-2012. However, only one focus group was conducted for all five river basins. The full potential of civil society participation has yet to be realized in Mendoza. Water governance is predominated by a technocratic, engineered, water management worldview (Montaña, 2008).

Irrigation is considered a key component to expand national agricultural productivity (Wheaton et al., 2008; Montaña et al., 2005). The SSRB is located within a region that has also experienced several multi-year droughts during the last century (Wheaton et al., 2008). As a product of the droughts of the 1920s and 1930s, the federal and provincial governments embarked in an institutional and infrastructure program that, among other things, promoted the development of irrigation (Daschuck \& Marchildon, 2006). Most of the irrigation infrastructure in Canada is found in the SSRB with Alberta having well over 60\% of Canada's irrigated land (ICID, 2010). Water supplies are already fully allocated in Alberta's portion of the basin (Alberta Environment, 2006), so the possibility of expanding irrigation as a coping capacity against future droughts is limited. In Mendoza, irrigation expansion occurs upstream with new viticulture, to the detriment of producers located downstream where desertification results; effectively the oasis is moved upstream to more powerful agricultural producers (Montaña, 2008; Montaña \& Boninsegna, forthcoming). This is an issue of equity expanded on below.

\subsection{Equity}

In Canada, interviews with participants, focus groups, studies of water related conflicts, and historical studies all confirmed that droughts result in institutional innovations and infrastructure development, which has increased significantly regional adaptive capacity (Diaz et al. 2009; Salas, et al, 2012; Diaz et al, 2012; Montaña, 2008). The same studies, however, confirm that this adaptive capacity is not distributed evenly. First Nation communities tend to be the most vulnerable due to particular conditions that characterize the integration of indigenous people in Canada (Mazgul \& Rojas, 2006). Communities in dry-land areas are also highly sensitive to water scarcities due to lack of access to irrigation and small and aging populations. Communities with well-established water infrastructure (storage reservoirs and distribution networks) and who utilize irrigation in periods of low precipitation were the most resilient (Wheaton et al., 2008). Further harm to communal identity and stability, people's sense of heritage, cultural integrity, informal systems of governance and trust-based relationships often are not part of policy and focus of water governance institutions. Preserving this social capital, and developing new styles of policy building and economic development relating to ecosystem and environmental preservation, are often neglected by institutions but would assist in building local and rural resilience.

In Mendoza, as in many places of Latin American, equity is a major concern in the water sector as well as in many aspects of social life. It is the hegemonic powers that have shaped a water bureaucracy that commands the appropriation and use of water and irrigated soil. Small oasis farmers are affected not only by hydroclimatic exposures, but also by other multiple socioeconomic exposures, and are vulnerable to the point of risking being expelled from the irrigation circuit and their lands liable to be ceded to urbanization or simply abandoned (Montaña \& Boninsegna, forthcoming). On the other hand, the goat breeders are also very vulnerable, living in the non-irrigated downstream land, dispossessed from their right to use the river water, and occupying a subordinate role in this hydraulic society. There is a lack of democratic representation of those with interests in water. The Inspections (overseeing surface water allocations) operates based on elections conducted by water rights holders. Those without water rights, such as downstream aboriginal communities, have no ability to participate in the water governance of the Inspections at any time, let alone in times of drought. The claims of 
these goat husbandry communities in time of droughts are not considered, let alone responded to.

In Mendoza, water infrastructures are built and maintained according to a hierarchy. In general terms, dams are built and operated by the provincial government; big conduction channels are built by the DGI, and minor conduction and distribution works are assumed by users that benefit from them (with some contributions from the DGI). But it is water wells the infrastructure that ultimately become key when facing extreme drought. Groundwater access depends on the producer's capacity to afford it, so it is the wealthiest that can drill wells and pump accordingly to their needs. Ability to respond to extreme drought is not as evident for those with old damaged wells or those who can't afford the construction or pumping or the well (Bustos et al., 2008).

The differences in the vulnerabilities and adaptive capacities between Argentina and Canada do relate to the different governance structures of each country. While Canada has a strong decentralized water governance structure residing in its provinces it lacks a current well-coordinated water strategy. The large number of stakeholders and institutional arrangements has produced a fragmented approach to the management of water resources, resulting in an unequal distribution of adaptive capacity. Some communities in the SSRB are more vulnerable than others, but none is without some degree of access to and benefit from water for drinking and sanitation. Some believe not having a federal Canadian water policy is a disadvantage especially in relation to preventing the privatization of water and ensuring the human right to water for all (Barlow, 2007).

\section{Conclusion}

Droughts are often regarded as disasters, but this research has shown them to also be opportunities for learning. After droughts both study areas have experienced institutional innovations and infrastructure development, which has increased significantly their regional adaptive capacity (Diaz et al 2009; Salas et al, 2012; Diaz et al, 2012; Montaña, 2008). Irrigation has allowed both study areas the ability to develop an oasis in otherwise dryland river basins; irrigation is regarded as a key adaptation, and has allowed expansion of both nations' agricultural productivity (Wheat et al., 2008; Montaña et al., 2005). Can this state of affairs continue into the future given the pressures of increased development and climate change on the two basins studied herein in Alberta and Mendoza? This paper has explored this question by utilizing in depth research projects in both areas exploring vulnerability and the institutional water governance regime and analyzing this data through the lens of adaptive governance. Based on this analysis, Table 1 outlined the major findings in respect of the institutional design principles of adaptive governance of Gupta et al., (2010) and Huntjens et al., (2012).

Several characteristics of Alberta's water law and policy show increased congruence with the principle of adaptive governance of responsiveness. These characteristics include the ability to transfer water interests in limited circumstances, extensive and facilitated local civil society participation in water policy setting, and the endorsement of the principle of integrated water planning. However, important characteristics exist in both Mendoza and Alberta limiting the adaptive governance of water. These include issues of coordination and integration between water institutions which hamper the ability of these institutions to respond quickly in the event of extreme weather events. Further, in light of climate change and anticipated extreme events, it is unclear in Alberta, whether increasing conflict between water stakeholders will be handled in a responsive, timely manner. It is very clear in Mendoza that this will be a challenge.

Ground water and surface water governance disconnects prevent reflexivity in respect of the governance system in Mendoza. One government institution acts completely independently and in contradiction of another. In Alberta data gaps exist in relation to water availability (which includes ground water and surface water and their inter-linkages); in Mendoza data gaps on water demand exist. These data gaps limit reflexivity and social learning occurring in Alberta and Mendoza.

Capacity concerns have arisen in both countries in respect of government reductions, cutbacks and staffing. Retirements of civil servants in Alberta are reducing capacity and an aging farming industry is inhibiting Mendoza. Staff reductions in Alberta result in reduced interaction of government institutions with the public. Although Alberta has a long history of public engagement, Mendoza has only embraced this governance process in small measures.

It is unclear that given climate change the same productive irrigation sector will continue in the two study areas. Irrigation which is not supplemented by some rains in Alberta or irrigation that needs to be fed by groundwater pumping in Mendoza would be more labour intensive, consume more energy and may require the heaviest infrastructure investments (Wheaton, et al., 2011; DGI, 2007). In Alberta, irrigation expansions has stalled. As well, as in Mendoza, some irrigators will benefit from a sort of differential land rent, this time not related to soil fertility but to access to good quality, abundant and relatively cheaper surface water. 
Vulnerable populations exist in both Alberta (dry land farmers and First Nations) and Mendoza (goat herders and small oasis farmers). Given the aforementioned trends in relation to adaptive governance the future for these vulnerable populations are tenuous. Weaknesses (such as institutional fragmentation, data gaps in respect of water, and capacity reductions) position powerful actors well into the future. Powerful actors, with better access to capital (social and financial) will be able to access information (by paying for it) and leverage institutional fragmentation to improve their position into the future. In Mendoza this is currently happening through ground water licensing and urban sprawl which occurs in an institutional vacuum well away from water licensing for irrigators. The current move to recognize the human right to water occurring in both countries needs further focus by all actors.

In order to counter the troubling trends identified, both countries would benefit from a comprehensive, consultative introspective consideration of their institutional water governance arrangements in light of the principles of adaptive governance. By addressing the weaknesses identified herein, improvements to the responsiveness, reflexivity, and informational access inherent in water governance systems with a mind to improving capacity and equity, will reduce vulnerability and position their respective communities into the future.

\section{Acknowledgements}

The research projects listed in the methodology were funded by the Social Science Research Council of Canada (SSHRC) and the InterAmerican Institute for Global Change Research (IAI).

\section{References}

Alberta Agriculture and Rural Development. (n.d.). Growing Forward 2 Programs Irrigation Efficiency. Retrieved from http://www.growingforward.alberta.ca/Programs?index.htm?contentId=IRRIG_EFF_ PRG\&useSecondary+true\&active+yes

Alberta Environment. (2006). Approved Water Management Plan for the South Saskatchewan River Basin (Alberta). $\quad$ Retrieved September 29, 2014, from http://environment.alberta.ca/documents/SSrb_Plan_Phase2.pdf

Andrews, E. (2012). Baseline Institutional Water Governance Report. Retrieved September 22, 2014, from http://www.parc.ca

Baars, E., Bastiaansen, A. P. M., \& Menenti, M. (1995). A User-Oriented and Quantifiable Approach to Irrigation Design. Water Resources Management, 9, 95-113. http://dx.doi.org/10.1007/BF00872462

Bakker, K. (2007). Eau Canada. The Future of Canada's Water. UBC Press, Toronto.

Barlow, M. (2007). Blue Covenant. McLelland and Stewart Ltd., Toronto.

Berkes, F., \& Folke, C. (Eds.). (1998). Linking sociological and ecological systems: management practices and social mechanisms for building resilience. Cambridge University Press, New York, New York, USA.

Boninsegna, J. y R. Villalba. (2006a). Los condicionantes geográficos y climáticos. Documento marco sobre la oferta hídrica en los oasis de riego de Mendoza y San Juan. Primer informe a la Secretaria de Ambiente y Desarrollo Sustentable de la Nación. 19pp.

Boninsegna, J. y R. Villalba. (2006b). Los condicionantes geográficos y climáticos. Documento marco sobre la oferta hídrica en los oasis de riego de Mendoza y San Juan. Segundo informe a la Secretaria de Ambiente y Desarrollo Sustentable de la Nación. 19pp.

Boninsegna, J., \& Delgado, S. (2002). Atuel River streamflow variations from 1575 to present reconstructed by tree rings their relationships to the Southern Oscillation. In D. Trombotto, \& R. Villalba (Eds.), IANIGLA, 30 Years of Basic and Applied Research on Environmental Sciences (pp. 31-34.). Zeta Editores, Mendoza, Argentina.

Brown, P. (2007). Global Warming. The Last Chance for Change. China: Reader's Digest and Dakinin Books.

Brunner, R. D., \& Steelman, T. A. (2005). Towards Adaptive Governance. In R. D. Brunner, T. A. Steelman, L. Coe-Juell, C. M. Cromley, C. M. Edwards, \& D. W. Tucker (Eds.), Adaptive Governance: Integrating science, policy and decision making. New York: Columbia University Press.

Burris, S., Drahos, P., \& Shearing, C. (2005). Nodal Governance. Australian Journal of Legal Philosphy, 30, 30-58.

Bustos, R. M., Saldi, R., \& de Rosas, L. (2008). Quién tiene la ultima palabra? Discurso Institucional vs. Redes 
sociales en la descentralización de la gestión del sistema de riego en la cuenca del Rio Mendoza. Temas y debates 15/ dossier/ agosto 2008. P. 83-96.

Cardston County. (2011). Chief Mountain, Cumulative Effects Study, Assessing the Footprint of Human Activity in Southwest Alberta, Cardston, Alberta. Retrieved from http://www.watertonbiosphere.com

Cook, J., Freeman, S., Levine, E., \& Hill, M. (2011). Shifting Course: Climate Adaptation for Water Management Institutions. World Wildlife Fund Inc., Washington, DC. Retrieved from http://adaptiveinstitutions.org/Shifting_Course.pdf

Corkal, D., Diaz, H., \& Sauchyn, D. (2011). Changing roles in Canadian Water Management: A Case Study of Agriculture and Water in Canada's South Saskatchewan River Basin. International Journal of Water Resources Development, 27(4), 647-664.

Daschuck, J., \& Marchildon, G. (2006). Historical Chronology of the Oldman River Dam Conflict. Research Report. IACC Project. Retrieved from http://www.parc.ca/mcri/pdfs/papers/iacc036.pdf

DGI (Departamento General de Irrigación), Gobierno de Mendoza. (2007). Plan Director de Ordenamiento de Recursos Hídricos - Informe Principal. Retrieved from http://www.dgi.gov.ar

DGI (Departamento General de Irrigación), Gobierno de Mendoza. (2013). Plan Estratégico de los Recursos Hídricos de Mendoza. Retrieved from http://www.dgi.gov.ar

DGI. (n.d.). Plan H2020. Retrieved from http://www.aqua.gov.ar/2020/

Diaz, A. E., \& Bertranou, A. (2004). Systemic Study of Water Management Regimes Global Water Partnership, South America. Retrieved from http://www.eclac.cl/samtac/noticias/documentosdetrabajo/8/23418/InAr00404.pdf

Diaz, H. et al. (2012). Vulnerability of Andean Communities to Climate Variability and Climate Change. In W. Leal (Ed.), Climate Change and the Sustainable Use of Water Resources (pp. 209-224). Springer, Berlin. http://dx.doi.org/10.1007/978-3-642-22266-5_13

Diaz, H., \& Hurlbert, M. (2011). Vulnerability and Adaptation to Climate Extremes in the Americas (VACEA) Methodology Document for Themes 1A and 1C (October 3, 2011) Research Report.

Diaz, H., \& Warren, J. (2012). RCAD - Rural Communities Adaptation to Drought, Research Report, August 2012, Regina: University of Regina and CPRC Press.

Diaz, H., Hadarits, M., \& Barrett-Deibert, P. (Eds.). (2009). IACC Final Report December 2009. Comparative Study of Dryland River Basins in Canada and Chile, Regina, CPRC Press. Retrieved from http://www.parc.ca/mcri/pdfs/papers/IACC_Final_Report_e.pdf

Diaz, H., Hurlbert, M., Warren, J., \& Corkal, D. (2009). Saskatchewan Water Governance Assessment Final Report. IACC Project. Retrieved from http://www.parc.ca/mcri/gov01.php

Dietz, R., Ostrom, E., \& Stern, P. C. (2003). The Struggle to Govern the commons. Science, 302(5652), 1907-1912. http://dx.doi.org/10.1126/science.1091015

El Sol. (2013). "Efecto Frigerio": Irrigación tiene frenada la autorización de nuevos pozos. Retrieved October 14 , 2014, from http://elsolonline.com/noticias/ver/1304/168818/-efecto-frigerio-irrigacion-tienefrenada-la-autorizacion-de-nuevos-pozos

Folke, C. (2006). Resilience: The emergence of a perspective for social-ecological systems analyses. Global Environmental Change, 16, 253-267. http://dx.doi.org/10.1016/j.gloenvcha.2006.04.002

Folke, C., Hahn, T., Olsson, P., \& Norberg, J. (2005). Adaptive Governance of Social-Ecological Systems. Annual Review of Environmental Resources, 30, 411-473. http://dx.doi.org/10.1146/annurev.energy.30.050504.144511

Foxon, R., Reed, M. S., \& Stringer, L. C. (2009). Governing long-term social-ecological change: What can the adaptive management and transition management approaches learn from each other? Environmental Policy and Governance, 19, 3-20. http://dx.doi.org/10.1002/eet.496

Global Water Partnership. (2009). Integrated Water Resources Management. Retrieved June 8, 2010, from Http://ww.gwptoolbox.org/index.php?option=com_content\&view=article\&id=8\&Itemid=3

Goodin, R. E. (1996). Institutions and their design. In R. E. Goodin (Ed.), Theory of Institutional design (pp. 1-53). Cambridge University Press, Cambridge, UK. http://dx.doiorg/10-1017/CB09780511558320002 
Government of Alberta. (2010). Alberta's Agriculture Drought Risk Management Plan, May 2010. Policy, Strategy and Intergovernmental Affairs Division, Retrieved from http://www1.agric.gov.ab.ca/\$department/deptdocs.nsf/all/ppe3883

Gunderson, L. (1999). Resilience, flexibility and adaptive management - antidotes for spurious certitude? Conservation Ecology, 3(1), 7.

Gunderson, L. H., \& Holling, C. S. (Eds.). (2002). Panarchy: Understanding Transformations in Human and Natural Systems. Washington: Island Press.

Gupta, J. et al. (2010). The Adaptive Capacity Wheel; a Method to Assess the Inherent Characteristics of Institutions to Enable the Adaptive Capacity of Society. Environment Science and Policy, 13, 459-471. http://dx.doi.org/10.1016/j.envsci.2010.05.006

Henson, R. (2006). The Rough Guide to Climate Change. London: Rough Guides.

Hill, M. (2012). Characterizing Adaptive Capacity in Water Governance Arrangements in the Context of Extreme Events. In W. Leal (Ed.), Climate Change and the Sustainable Use of Eater Resources. Spinger. http://dx.doi.org/10.1007/978-3-642-22266-5_22

Holling, C. S. (Ed.). (1978). Adaptive environmental assessment and management. John Wiley, New York New York USA.

Huitema, D., Mostert, E., Egas, W., Moellenkamp, S., Pahl-Wostl, C., \& Yulcin, R. (2009). Adaptive Water Governance: Assessing the Institutional Prescriptions of Adaptive Co-Management from a Governance Perspective and Defining a Research Agenda. Ecology and Society, 14(1), 26-45.

Huntjens, P. et al. (2012). Institutional Design Propositions for the Governance of Adaptation to Climate Change in the Water Sector. Global Environmental Change, 22, 67-81. http://dx.doi.org/10.1016/j.gloenvcha.2011.09.015

Hurlbert, M. A. (2006). Water Law in the South Saskatchewan River Basin (Alberta/Saskatchewan) prepared for and posted in 2006 on research team site of Institutional Adaptation to Climate Change Project, SSHRC MCRI.

Hurlbert, M., \& Diaz, H. (2013). Water Governance in Chile and Canda- A comparison of adaptive characteristics. Ecology and Society, 18(4), 61-76. http://dx.doi.org/10.5751/ES-06148-180461

Hurlbert, M., Corkal, D. R., \& Diaz, H. (2010). Government Institutions and Water Policy (Chapter 18). In D. Sauchyn, H. Diaz, \& S. Kulshreshtha (Eds.), The New Normal, The Canadian Prairies in a Changing Climate. Canadian Plains Research Center, Regina.

Hurlbert, M., Mussetta, P., \& Ivars, J. (2014). Forthcoming A Multi-level Analysis and Comparison of Climate Change Policies in Argentina and Canada. Policy and Climate Change, 2.

ICID (International Commission on Irrigation and Drainage). (2010). Country Profile - Canada, Irrigation. Retrieved July 6, 2010, from http://www.icid.org/cp_canada.html

Intergovernmental Panel on Climate Change (IPCC). (2001). Summary for policy makers. Climate Change 2001: Impacts, adaptations and vulnerability. Geneva, $\mathrm{CH}$ : IPCC.

IPCC. (2012). Summary for Policymakers. In C. B. Field, V. Barros, T. F. Stocker, D. Qin, D. J. Dokken, K. L. Ebi, ... P. M. Midgley (Eds.), Managing the Risks of Extreme Events and Disasters to Advance Climate Change Adaptation (pp. 1-19). A Special Report of Working Groups I and II of the Intergovernmental Panel on Climate Change. Cambridge University Press, Cambridge, UK, and New York, NY, USA,.

IPCC. (2014). Summary for Policymakers. In O. Edenhofer, R. Pichs-Madruga, Y. Sokona, E. Farahani, S. Kadner, K. Seyboth, ... J. C. Minx (Eds.), Climate Change 2014, Mitigation of Climate Change. Contribution of Working Group III to the Fifth Assessment Report of the Intergovernmental Panel on Climate Change. Cambridge University Press, Cambridge, United Kingdom and New York, NY, USA.

Johns, C., \& Rasmussen, K. (2008). Institutions for Water Resource Management in Canada. In M. Sproule-Jones, C. Johns, \& T. Heinmiller (Eds.), Canadian Water Politics. Conflicts and Institutions (pp. 59-89). McGill-Queens University Press, Montreal.

Lebel, L. Anderies, J. M., Cambell, C., Folke, S., Hatfield-Dodds, S., Hughes, T. P., \& Wilson J. (2006). Governance and the capacity to manage resilience in regional social-ecological systems. Ecology and Society, 11(1), 19. 
Lee, T. R. (1990). Managing Water Resources in Latin America. Natural Resources Journal, 30, 581-607.

Magzul, L., \& Rojas, A. (2006). Report on the Blood Tribe (Kainai Nation): Community Vulnerabilities. Retrieved July 5, 2010, from http://www.parc.ca/mcri/pdfs/papers/iacc051.pdf

Masiokas, M. H., Villalba, R., Luckman, B. H., Montaña, E., Cristie, D., Beman, E., ... Mauget, S. (2013). Recent and historic Andean snowpack and stream flow variations and vulnerability to water shortages in central-western Argentina. In R. Pielke (Ed.), Water Encyclopedia. Vulnerability Volume, Elsevier Sciences.

McDowell, J., \& Hess, J. (2012) Accessing adaptation: Multiple stressors on livelihoods in the Bolivian highlands under a changing climate. Global Environmental Change, 22(2), 342-352. http://dx.doi.org/10.1016/j.gloenvcha.2011.11.002

MDZPolitica. (2013). Los pozos del escandalo: la justicia acepto un amparo. MDZ 1 dew Abril de 2013. Retrieved October 14, 2014, from http://www.mdzol.com/nota/456598/

Mollenkamp, S., \& Kastens, B. (2009). Institutional Adaptation to Climate Change: Current Status and Future Strategies in the Elba Basin, Germany. In F. Luwig et al. (Eds.), Climate Change Adaptation in the Water Sector. Earthscan: London.

Montaña, E. (2008). Las disputas territoriales de una sociedad hídrica. Conflictos en torno al agua en Mendoza, Argentina. Revista Interamericana de Economía Ecológica, REVIBEC (FLACSO, Ecuador), 9, 1-17.

Montaña, E. (2011). Escenarios espaciales del cambio ambiental global en áreas de regadío. Paper presented and published in full text at VII Congreso Ibérico Sobre Gestión y Planificación del Agua, desarrollado en Talavera de la Reina, Madrid, febrero de 2011.

Montaña, E. (2012). Escenarios de cambio ambiental global, escenarios de pobreza rural. Una mirada desde el territorio. Buenos Aires: CLACSO-CROP.

Montaña, E. (2013). Cambio ambiental global y pobreza rural. Alternativas de política. Investigación y Políticas \# 13 CLACSO-CROP, Serie Documentos Breves: Investigación y Políticas.

Montaña, E., \& Boninsegna, J. A. (2014). Drought in the Oases of Central Western Argentina. In H. Diaz, J. Warren, \& M. Hurlbert (Eds.), Drought, Calgary. Alberta: University of Calgary Press.

Montaña, E., Torres, L. M., Abraham, E. M., Torres, E., \& Pastor, G. (2005). Los espacios invisibles. Subordinacion marginalidad y exculsion de los territories no irrigados en las tierras secas de Mendoza, Argentina. Región y Sociedad, 17(32).

Mostert, E., Pahl-Wostl, C., Rees, Y., Searle, B., Tàbara, D., \& Tippet, J. (2007). Social learning in European river-basin management: barriers and fostering mechanisms from 10 river basins. Ecology and Society, 12(1), 19. Retrieved from http://www.ecologyandsociety.org/vol12/iss1/art19/

Mussetta, P. (2013). Secondary Source Research and Literature Review. Unpublished Manuscript. INHUSA.

Olsson, P., Gunderson, L. H., Carpenter, S. R., Ryan, P., Lebel, L., Folke, C., \& Holling, C. S. (2006). Shooting the Rapids: Navigating Transitions to Adaptive Governance of Socio-Ecological Systems. Ecology and Society, 11(1), 1-18.

Pahl-Wostl, C. (2010). Water governance in times of change. Environmental Science \& Policy, 13, 567-570. http://dx.doi.org/10.1016/j.envsci.2010.09.004

Parry, M. L., Canziani, O. F., Palutikof, J. P., Linden, P. J. van der, \& Hanson, C. E. (Eds.). (2007). Summary for Policymakers. Pp. 7-22 in Climate Change 2007: Impacts, Adaptation and Vulnerability. Contribution of Working Group II to the Fourth Assessment Report of the Intergovernmental Panel on Climate Change. Cambridge: Cambridge University Press.

Pinto, M. (2006). La administración y gestión del agua en Mendoza. III Jornadas de Actualización en Riego y Fertirriego. Retrieved from http://www.inta.gov.ar/mendoza/Jornadas/Trabajospresentados/Pinto.pdf

Pochat, V., Natenzon, C. E., \& Murgida, A. M. (2006). Argentina, Country Case Study on Domestic Policy Frameworks for Adaptation in the Water Sector. Background information for presentation given by Victor Pochat at the Annex I Expert Group Seminar in Conjunction with the OECD Global Forum on Sustainable Development, March 28, 2006. Retrieved September 30, 2014, from http://www.oecd.orgéenvironmentéccé36448827.pdf

Prado, S. (2008). Institutional Adaptations to Climate change SSHRC MCRI Project. Report on Community Vulnerability Assessment of Taber, Alberta. Retrieved from http://www.parc.ca/mcri/pdfs/papers/iacc066.pdf 
Rojas, A., Reyes, B., Magzul, L., Morales, H. L., Borquez, R., \& Swartz, E. (2007). Analysis of the Role of Institutions in Water Conflicts Final Report. IACC Project Report. Retrieved from http://www.parc.ca/mcri/iacc057.php

Salas, S. et al. (2012). Vulnerability to Climate Change. Challenges to Adaptation in the Basins of Elqui and Mendoza, Editorial del Norte, La Serena.

Salomon, M. (2009). La gestión hídrica desde las propias organizaciones de usuarios. Asociación de Inspecciones de Cauce $1^{\circ}$ Zona Río Mendoza (Argentina). XV Congreso Nacional de Irrigación. Panel Internacional. (XVII) Memorias del Congreso Puerto Vallarta. Jalisco. México.

Scholz, J. T., \& Stiftel, B. (Eds.). (2005). Adaptive Governance and Water conflict. New Institutions for collaborative Planning. Resources for the future. Washington, D.C.

Secretaría de Ambiente, Gobierno de Mendoza. (2010). Guía del Diagnóstico Preliminar. Plan Estratégico de Desarrollo de Mendoza. Mendoza, Retrieved from http://www.oikosredambiental.org/documentos/docmdz2cem.pdf

Siebenhuner, B. (2008) Learning in international organizations in global environmental governance. Global Environmental Politics, 8(4), 92-116. http://dx.doi.org/10.1162/glep.2008.8.4.92

Sivera, M. (2013a). Por los pozos de Agrelo, rechazaron un recurso contra Irrigación. Los Andes, Mendoza. Retrieved October 14, 2014, from http://www.losandes.com.ar/notas/2013/4/17/pozos-agrelo-rechazaron-recurso-contra-irrigacion-708729.asp

Sivera, M. (2013b). Irrigación anuló pozos polémicos y enfrentará ola de amparos. Los Andes, Mendoza. Retrieved

from http://www.losandes.com.ar/notas/2013/3/9/irrigacion-anulo-pozos-polemicos-enfrentara-amparos-701111.a $\mathrm{sp}$

Smit, B., \& Wandel, J. (2006). Adaptation, adaptive capacity and vulnerability. Global Environment Change, 16, 282-292. http://dx.doi.org/10.1016/j.gloenvcha.2006.03.008

Stewart, J. (2011). Watershed Management and Cumulative Effects: What Private Landowners Need to Know. Paper presented March 18, 2011 at the National Environment, Energy and Resource Law Summit of the Canadian Bar Association, Banff, Canada.Venema, H. \& Drexhage, J. (2009). The Need for Adaptive Policies. In D. Swanson, \& S. Bhadwal (Eds.), Creating Adaptive Policies. A Guide for Policy-Making in an Uncertain World. New Delhi: Sage. Retrieved from http://www.idrc.ca/openbooks

UNCuyo (Universidad Nacional de Cuyo). (2004). Marco estratégico para la provincia de Mendoza Diagnóstico fisico-ambiental. Universidad Nacional de Cuyo. Mendoza. Retrieved from http://www.oikosredambiental.org/documentos/docar1unc.pdf

Venema, H., \& Drexhage, J. (2009). The need for adaptive policies. In D. Swanson, \& S. Bhadwal (Eds.), Creating adaptive policies: a guide for policy making in an uncertain world (pp. 1-11). Sage, New Delhi, India. http://dx.doi.org/104135/9788132108245.nl

Wandel, J. (2009). Alberta Governance Assessment Report. Retrieved from http://www.parc.ca/mcri/pdfs/papers/gov02.pdf

Wheaton, E., Kulshreshtha, S., Wittrock, V., \& Koshida, G. (2008). Dry Times: Hard Lessons from the Canadian Drought of 2001 and 2002. The Canadian Geographer, 52(2), 241-262. http://dx.doi.org/10.1111/j.1541-0064.2008.00211.x

Wheaton, E., Wittrock, V., Koshida, G., Siemens, E., \& Smeh, D. (2011). What are the Benefits of Drought? Concepts and Examples to Promote Effective Climate Adaptation Information Services' March, 2011. Prepared for Adaptation and Impacts Research Section, Environment Canada By Saskatchewan Research Council, Environment and Forestry Division and University of Saskatchewan, Saskatchewan Research Council, Environment and Forestry Division and Adaptation and Impacts Research Section, Environment Canada SRC Publication No. 13077-1E11.

Young, O. R. (2011). Land use, environmental change, and sustainable development: the role of institutional diagnostics. Int. J. Commons, 5, 66-85. 


\section{Notes}

Note 1. Note that the terminology of dimensions or of "institutional design principles" and the content of these principles are by no means consistent. Some authors term them "evaluative criteria" (Ostrom 2011) or even "elements" of adaptive institutions (Mollenkamp and Kastens 2009).

Note 2. The current drought plan for Alberta focuses only on short-term coping strategies at the producer level (Government of Alberta, 2010).

\section{Copyrights}

Copyright for this article is retained by the author(s), with first publication rights granted to the journal.

This is an open-access article distributed under the terms and conditions of the Creative Commons Attribution license (http://creativecommons.org/licenses/by/3.0/). 